\section{Normal complement in early poststreptococcal glomerulonephritis}

Patients with acute poststreptococcal glomerulonephritis are usually found to have reduced serum concentrations of the third component of complement (C3), properdin, and total haemolytic complement (CH50). ${ }^{1}$ We report here a unique variation of this pattern.

\section{Case report}

A previously healthy 71 -year-old boy was admitted to hospital after one day of macroscopic haematuria. Blood pressure was $110 / 80 \mathrm{~mm} \mathrm{Hg}$. Urine had a specific gravity of 1.010 , contained protein (trace to + ), and had more than 25 red blood cells per high power field but no casts. Complete blood count and smear showed unremarkable findings. No antinuclear antibody was present. Oral erythromycin was given for 10 days. The day before renal biopsy the blood pressure was $120 / 90 \mathrm{~mm} \mathrm{Hg}$, urinary protein excretion $794 \mathrm{mg} / 24$ hours, and creatinine clearance $15 \mathrm{ml} / \mathrm{min} / 1.73 \mathrm{~m}^{2}$. Initial antistreptolysin $\mathrm{O}$ titre was normal but subsequently increased (see figure). Because of progressive uraemia of uncertain cause, a percutaneous renal biopsy was performed on day 10 . His condition gradually improved without other treatment.

Renal biopsy-Light microscopy of the renal biopsy showed 19 glomeruli, all of which were enlarged and diffusely hypercellular with proliferation and swelling of endothelial and mesangial cells. A single glomerular epithelial crescent was noted. Fluorescent microscopy using specific fluoresceinlabelled antisera showed diffusely positive staining along the capillary wall for IgG, IgM, C3, and properdin in a granular pattern. Electron microscopy showed rare subepithelial deposits.

Complement studies-The functional titrations were performed using specific cellular intermediates. ${ }^{2}$ Protein levels of $\mathrm{Clq}, \mathrm{C} 4, \mathrm{C} 3$, and properdin were measured by radial diffusion or rocket electrophoresis using monospecific antisera. ${ }^{2} \mathrm{CH}^{50}, \mathrm{C} 4$, and $\mathrm{C} 2$ in the initial serum specimen (day 3 ) were above the mean of our normal population, ${ }^{2}$ though still within two standard deviations. This initial serum specimen also had normal protein concentrations of $\mathrm{C} 4, \mathrm{C} 3$, and properdin but high normal factor B levels (see figure). $\mathrm{CH}^{50}$ and haemolytic $\mathrm{Cl}$ on day 10 were below the normal range and both functional $\mathrm{C} 4$ and $\mathrm{C} 2$ concentrations had decreased though they were not abnormal. $\mathrm{C} 3$ and properdin were considerably below normal $(<2 \mathrm{SD})$ Serum $\mathrm{C} 4$ and factor B protein concentrations had fallen slightly (see figure). Protein measurements of $\mathrm{C} 4$ and factor $\mathrm{B}$ then gradually increased while haemolytic $\mathrm{C} 4$ and $\mathrm{C} 2$ concentrations also tended to increase. By day $25 \mathrm{C} 3$, properdin, and $\mathrm{CH}^{50}$ had all returned to normal range, and both $\mathrm{C} 3$ and properdin showed high normal levels when last examined on day 85. A serum factor from the patient which partially cleaved $\mathrm{C} 3$ of normal serum by immunoelectrophoretic criteria was detected on days 3 and 10, but its concentration subsequently decreased.

\section{Comment}

This case calls attention to an unreported complement profile in poststreptococcal glomerulonephritis. Normal or high normal serum complement components ( $\mathrm{CH} 50, \mathrm{C} 1, \mathrm{C} 4, \mathrm{C} 2, \mathrm{C} 3$, properdin, and factor B) were present three days after the onset of gross haematuria and the characteristically decreased levels of $\mathrm{C} 3$, properdin, and $\mathrm{CH} 50$ were not found until day 10 .

We think that this patient was first studied very early in the progression of acute poststreptococcal glomerulonephritis, when complement consumption, though present, was adequately compensated by an increased synthetic rate. It has been proposed that C3 breakdown products decrease $\mathrm{C} 3$ synthesis, ${ }^{3}$ and possibly this patient was studied before decreased synthesis of $\mathrm{C} 3$ was induced. Radioactive turnover studies of complement components would be required to prove this. A C3-activating factor was detected and a similar or identical factor has been reported in acute poststreptococcal glomerulonephritis and chronic membranoproliferative glomerulonephritis. Sequential changes in complement and C3-activating factor similar to those we saw have been reported in a patient with pneumococcal glomerulonephritis, but poststreptococcal glomerulonephritis was not completely excluded. ${ }^{4}$

Experimental studies of nephritis ${ }^{5}$ are consistent with our hypothesis that our patient was studied early in the course of his disease,

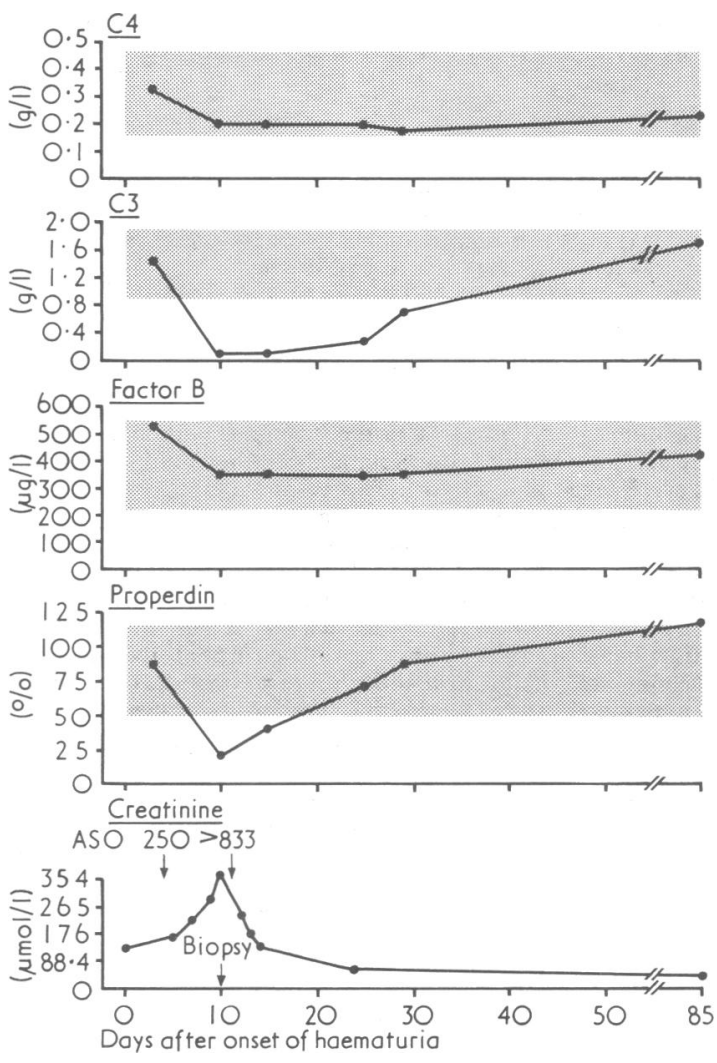

Serum creatinine and serum complement component protein titres $(\mathrm{C} 4, \mathrm{C} 3$, factor $\mathrm{B}$, and properdin) in patient with acute poststreptococcal glomerulonephritis. Shaded areas are normal range $( \pm 2 S D)$. Properdin is expressed as percentage of reference serum.

Conversion: $S I$ to traditional units-Creatinine: $1 \mu \mathrm{mol} / 1 \approx 0.0113 \mathrm{mg} /$ $100 \mathrm{ml}$.

when glomerulonephritis was already present but when the serum complement catabolic rate was more than compensated for by the simultaneously increased complement synthesis.

1 William, D G, et al, Clinical and Experimental Immunology, 1974, 391, 1974.

2 McLean, R H, et al, American fournal of Medicine, 1976, 60, 60.

${ }^{3}$ Charlesworth, J A, et al, fournal of Clinical Investigation, 1974, 53, 1578

4 Hyman, L R, et al, American fournal of Medicine, 1975, 58, 810.

${ }^{5}$ Schwab, L, et al, fournal of Experimental Medicine, 1950, 91, 505.

This work was supported by the Charles $\mathrm{H}$ Hood Foundation and the Connecticut Research Foundation and United States Public Health Service, National Institutes of Health. We thank Dr W B Henry for referring this patient.

Requests for reprints should be addressed to Dr Robert H McLean.

(Accepted 28 fanuary 1977)

\section{University of Connecticut Health Centre, Farmington, Connecticut} 06032, USA

ROBERT H MCLEAN, MD, assistant professor, department of paediatrics MARK A SCHRAGER, MD, fellow in rheumatology

NAOMI F ROTHFIELD, MD, professor, department of medicine

Hartford Hospital, Hartford, Connecticut

MARTIN M BERMAN, MD, department of pathology 